\title{
Data report: compressional and shear wave velocity measurements on sediment in the hanging wall and footwall of megasplay fault, NanTroSEIZE Stage $\mathbf{1}^{1}$
}

\author{
Y. Hashimoto, ${ }^{2}$ H.J. Tobin, ${ }^{3}$ M. Knuth, ${ }^{3}$ and A. Harada ${ }^{2}$
}

\section{Chapter contents}

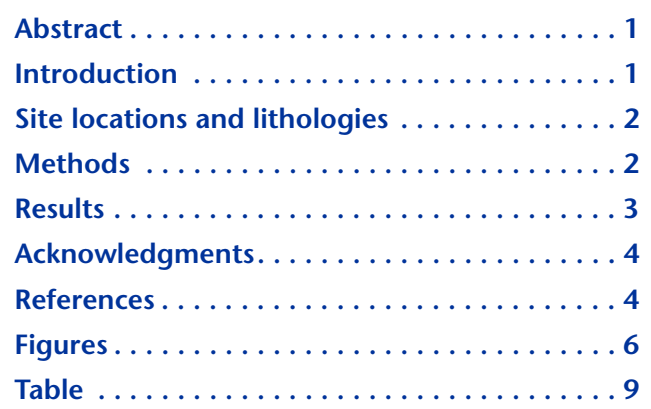

${ }^{1}$ Hashimoto, Y., Tobin, H.J., Knuth, M., and Harada, A., 2011. Data report: compressional and shear wave velocity measurements on sediment in the hanging wall and footwall of megasplay fault, NanTroSEIZE Stage 1. In Kinoshita, M., Tobin, H., Ashi, J., Kimura, G., Lallemant, S., Screaton, E.J., Curewitz, D., Masago, H., Moe, K.T., and the Expedition 314/315/316 Scientists, Proc. IODP, 314/315/316: Washington, DC (Integrated Ocean Drilling Program Management International, Inc.). doi:10.2204/iodp.proc.314315316.217.2011 2Department of Applied Science, Kochi University, Kochi 780-8520, Japan. Correspondence author: hassy@kochi-u.ac.jp

${ }^{3}$ Department of Geoscience, University of Wisconsin-Madison, Madison WI 53706, USA.

\section{Abstract}

Compressional and shear wave velocities were examined for sediments from the hanging wall and footwall of the megasplay fault in the Nankai accretionary prism, obtained during Integrated Ocean Drilling Program (IODP), Nankai Trough Seismogenic Zone Experiment (NanTroSEIZE) Stage 1. The samples were cored at Expedition 315 Site C0002 and Expedition 316 Site C0004. Three samples were tested from each site. At Site C0002, one sample is from forearc basin sediments and two samples are from accreted sediments. At Site C0004, one sample is from slope-apron sediments and two samples are from underthrust sediments in the footwall of the megasplay fault. Laboratory tests were conducted with controlled pore fluid pressure.

Compressional wave velocity covered a range from $\sim 2010$ to $2370 \mathrm{~m} / \mathrm{s}$ at Site C0002 and $\sim 1790$ to $2200 \mathrm{~m} / \mathrm{s}$ at Site C0004, both under hydrostatic fluid pressure conditions. Shear wave velocity ranged from $\sim 720$ to $950 \mathrm{~m} / \mathrm{s}$ at Site C0002 and 650 to $940 \mathrm{~m} / \mathrm{s}$ at Site C0004. $V_{\mathrm{P}} / V_{\mathrm{S}}$ ranged from $\sim 2.5$ to 2.8 at Site C0002 and $\sim 2.3$ to 2.7 at Site C0004, with a mean of $\sim 2.6$. Computed shear modulus ranged from $\sim 1.0$ to $1.88 \mathrm{GPa}$ for Site C0002 and $\sim 0.79$ to $1.76 \mathrm{GPa}$ at Site C0004. Bulk modulus ranged from $\sim 6.60$ to $9.24 \mathrm{GPa}$ at Site C0002 and from $\sim 4.22$ to $\sim 7.17 \mathrm{GPa}$ at Site C0004.

\section{Introduction}

Accretionary prism sediments are initially unlithified and have $>60 \%$ porosity (e.g., Bray and Karig, 1985). Because of progressive sedimentation or underthrusting along the décollement, the unlithified sediments become lithified rocks at depth. The degree of lithification in a package of sediments can be examined quantitatively using physical properties. We focused on compressional and shear wave velocities to examine the state of lithification because these parameters are expressions of elastic moduli. The evolution of elastic moduli in sediments is strongly related to diagenetic and strengthening processes resulting from porosity decrease, fluid release, cementation, and strain history. Variability within the accretionary complex and along the décollement may have implications for wedge geometry, fluid migration, and seismogenesis (e.g., Bangs and Westbrook, 1991; von Huene and Scholl, 1991; Moore and Vrolijk, 1992; Erickson and Jarrard, 1998; Bilek and Lay, 1999; Moore and Saffer, 2001; Gettemy and Tobin, 2003; Saffer, 2007). 
In this study, we describe the results of laboratory measurements of compressional and shear wave velocities and related physical properties such as shear and bulk moduli of sediments obtained from Integrated Ocean Drilling Program (IODP) Expedition 315 Site C0002 and IODP Expedition 316 Site C0004. The results can be compared with other velocity or physical property data of sediments from accretionary prisms (e.g., Gettemy and Tobin, 2003; Hashimoto et al., 2010; Raimbourg et al., 2011). All sites are located in the hanging wall and footwall of the megasplay fault in the Nankai accretionary prism (see the "Expedition 315 summary" chapter [Ashi et al., 2009] and the "Expedition 316 summary" chapter [Screaton et al., 2009]). Shear wave velocity for accretionary sediments has only rarely been reported (e.g., Gettemy and Tobin, 2003; Tsuji et al., 2006). Measuring the $S$-wave velocity of unlithified sediments at in situ conditions can be difficult, but $S$-wave velocity is needed to obtain elastic moduli. We conducted careful measurements and signal processing to obtain $S$-wave velocities.

\section{Site locations and lithologies \\ Site $\mathrm{C0002}$}

Site C0002, drilled during Expedition 315, is located at the southern margin of the Kumano forearc basin (Figs. F1A, F1B) (see the "Expedition 315 Site C0002" chapter [Expedition 315 Scientists, 2009]). The lithology of this site is divided into four units: upper forearc basin (Unit I), lower forearc basin (Unit II), basal (starved) basin (Unit III), and upper accretionary prism (Unit IV) (Fig. F1D).

Units I and II are composed mainly of dark gray hemipelagic silty clay with minor fine sand, silt turbidites, and volcanic ash. The dominant lithologies of Unit III are greenish-gray, gray, and gray-brown silty claystones. Calcareous nannofossils are abundant in Unit III, and a suite of Pliocene biostratigraphic events was recognized in the short depth interval within this unit (Fig. F1D).

The boundary between Units III and IV is an unconformity. The dominant lithology of Unit IV is gray to greenish-gray silty claystone. The silty claystones here are highly fractured. Unit IV is interpreted to be of late Miocene age on the basis of biostratigraphic analysis. This unit is interpreted as accreted sediments.

One sample from Unit II (forearc basin sediments) and two samples from Unit IV (accreted sediments) are examined in this study.

\section{Site $\mathrm{C0004}$}

Site C0004, drilled during Expedition 316, is located at the edge of the megasplay fault seaward of Site C0001 (Figs. F1A, F1B) (see the "Expedition 316
Site C0004" chapter [Expedition 316 Scientists, 2009]). This site is divided into four units on the basis of lithology and age (Fig. F1C).

Unit I is composed mainly of greenish-gray silty clay containing nannofossils (up to $25 \%$ ). The boundary between Units I and II is an unconformity.

Unit II is divided into two subunits on the basis of lithology (Fig. F1C). Subunit IIA comprises greenishgray synsedimentary breccia with rounded to subangular clasts of pebble size. Both the matrix and the clasts are composed of dark greenish-gray silty clay. This unit is interpreted as slump or mass wasting deposits (see the "Expedition 316 Site C0004" chapter [Expedition 316 Scientists, 2009]). Subunit IIB also consists of mostly dark greenish-gray silty clay, but the breccia is only rarely observed.

Unit III includes relatively abundant ash layers within hemipelagic silty clays. The boundaries between Units II and III and between Units III and IV might be faults because biostratigraphic age reversals have been identified around the boundaries.

The dominant lithology of Unit IV is dark olive-gray silty clay with a moderate amount of calcareous nannofossils. This unit is considered to have formed in a lower trench-slope environment and underthrust the footwall of the megasplay fault.

In this study, one sample from Subunit IIA (slope apron sediments) and two samples from Unit IV (underthrust sediments) were examined. The samples from Subunit IIA were selected from a homogenized part within the synsedimentary breccia.

\section{Methods}

The design of the experiment is similar to that employed in other studies of saturated marine sediments (e.g., Tobin et al., 1994; Tobin and Moore, 1997; Gettemy and Tobin, 2003; Hashimoto et al., 2010).

In the velocity measurements, two pumps (Teledyne ISCO $1000 \mathrm{D}$ syringe pump) were used to control pore fluid pressure and confine pressure. The pore pressure of $500 \mathrm{kPa}$ was kept under drained conditions. Confining (effective) pressure was increased stepwise in the measurements. Velocity measurements were conducted under isotropic pressure conditions. Confining pressure was pressurized in $10 \mathrm{~s}$ and maintained for $24 \mathrm{~h}$ for the next step. The pressure intervals depended on the samples, ranging from 100 to $1000 \mathrm{kPa}$ (Fig. F2). An in situ effective pressure was approximated for each sample from the sediment bulk density and hydrostatic pore fluid pressures at the depth of recovery (Table T1). The maximum effective pressure for each test was the in 
situ effective pressure. Lead zirconate titanate (PZT) shear wave transducers $(1 \mathrm{MHz})$ were used in a source-receiver pair to measure wave speed. PZT in a shear orientation generates a weak compressional mode in addition to its primary shear mode. This allowed us to identify $P$ - and $S$-wave arrivals in each test, although the $S$-wave arrival time was often difficult to locate precisely within the coda of the $P$-wave arrival. Axial displacements were measured during the experiments. Porosity changes were not obtained.

We found that the $S$-wave arrival was consistent across an array of waveforms at different effective pressures, although the error can be as large as $\sim 2 \mu \mathrm{s}$ $(\sim 5 \%$ error in shear wave velocity). Errors for $P$-wave velocity, bulk moduli, and shear moduli are $\sim 2 \%$, $\sim 5 \%$, and $\sim 10 \%$, respectively.

Three samples for each site were examined (Fig. F1C, F1D). At Site C0002, one sample is from forearc basin sediments (Core 315-C0002B-32R [Sample C2B-32R]) and two samples are from upper accreted sediments (Cores 315-C0002B-51R and 61R [Samples C2B-51R and C2B-61R]) (Fig. F1D). At Site C0004, one sample is from sedimentary breccia (Core 315-C0004C-12X [Sample C4C-12X]) and two samples are from underthrusted slope apron sediments (Cores 315-C0004C41R and 49R [Samples C4C-41R and C4C-49R]), located below a fault (Fig. F1C).

Samples were formed into a cylindrical shape $\sim 3.8 \mathrm{~cm}$ in diameter and $\sim 5-6 \mathrm{~cm}$ in length.

\section{Results}

Change in compressional wave velocity with effective pressure is shown in Figure F2. Velocities from Sites C0002 and C0004 ranged from 1430 to $\sim 1910 \mathrm{~m} / \mathrm{s}$ and $\sim 1700$ to $\sim 2010 \mathrm{~m} / \mathrm{s}$, respectively, at low effective pressures as high as $500 \mathrm{kPa}$ (Fig. F2). Velocity increases with effective pressure. Although Sample C2B-32R shows higher velocity than Sample C2B-51R at low effective pressure, the slope in wave speed versus effective pressure is relatively flatter. The slopes for Samples C2B-51R and C2B-61R are almost parallel. For Site C0004, the relationships between wave speed and effective pressure for forearc basin sediments and underthrust sediments have similar slope angles (Fig. F2).

Porosity was corrected to remove smectite effects from onboard porosity measurements using Brown and Ransom (1996)'s method; smectite content was estimated by X-ray diffraction analysis (Guo et al., 2009). Representative velocities were taken under hydrostatic conditions assuming the in situ setting is consistent with hydrostatic pore pressure. Porosity, compressional and shear wave velocities, and related properties are shown in Table T1.
Corrected porosity is $\sim 37.4 \%-27.0 \%$ for Site $\mathrm{C} 0002$ and $\sim 46.8 \%-38.9 \%$ for Site C0004. Compressional wave velocity is $\sim 2010-2370 \mathrm{~m} / \mathrm{s}$ for Site C0002 and $\sim 1790-2200 \mathrm{~m} / \mathrm{s}$ for Site C0004 under hydrostatic pore pressure conditions. The relationship between porosity and compressional wave velocity is shown in Figure F3A. Porosity and compressional wave velocity for Site C0001 (Hashimoto et al., 2010) are also included in Figure F3A for comparison. Open symbols represent cover sediments (slope-apron sediment or forearc basin sediments) for all sites; solid symbols represent sediments below the cover sediments, such as accreted sediments for Sites C0001 and $\mathrm{C0002}$ and underthrust sediments for Site C0004. At Site C0001, the relationship between porosity and compressional wave velocity for slopeapron sediments has a lower slope angle than that for other sediments, although the data for Sites C0002 and C0004 are more limited.

Shear wave velocity is $\sim 720-950 \mathrm{~m} / \mathrm{s}$ for Site C0002 and $\sim 650-940 \mathrm{~m} / \mathrm{s}$ for Site C0004 under hydrostatic pore pressure conditions. The relationship between porosity and shear wave velocity is presented in Figure F3B. Because the number of samples for shear wave velocity measurements is very limited, it is difficult to compare velocity-porosity relationships between forearc basin sediments and accreted sediments at Site C0002 or between slope-apron sediments and underthrust sediments at Site C0004. Porosity at Site C0004 is higher than that at Site C0002 in samples with almost the same shear wave velocities.

$V_{\mathrm{p}} / V_{\mathrm{S}}$ is $\sim 2.5-2.8$ for Site $\mathrm{C0002}$ and $\sim 2.3-2.7$ for Site C0004, with a mean of $\sim 2.6$ (Fig. F3C; Table T1). $V_{\mathrm{p}} / V_{\mathrm{S}}$ for forearc basin sediments (Site C0002) and slope-apron sediments (Site C0004) are slightly higher than those for other sediments.

From compressional and shear wave velocities, shear modulus $(\mu)$ and bulk modulus ( $\kappa)$ at specific effective pressures and porosities can be obtained, assuming that samples are isotropic and linearly elastic bodies, using the following formulas:

$$
\begin{gathered}
\mu=\rho_{\mathrm{bw}} V_{\mathrm{s}}^{2} \text { and } \\
\kappa=\rho_{\mathrm{bw}} V_{\mathrm{P}}^{2}-4 / 3 \mu,
\end{gathered}
$$

where $\rho_{\mathrm{bw}}$ is wet bulk density from moisture and density data.

The computed shear modulus is $\sim 1.0-1.88 \mathrm{GPa}$ for Site C0002 and $\sim 0.79-1.76 \mathrm{GPa}$ for Site C0004. The bulk modulus is $\sim 6.60-9.24 \mathrm{GPa}$ for Site C0002 and 4.22-7.17 GPa for Site C0004 (Table T1). Both are under hydrostatic fluid pressure conditions. 


\section{Acknowledgments}

We thank Brian Hess, John Fournelle, Lee Powell, Lee Putman, and Neal Lord for their help with sample treatments and laboratory measurements. This research used samples provided by the Integrated Ocean Drilling Program. The work of Y. Hashimoto is supported in part by the Japan Society for the Promotion of Science Postdoctoral Fellowship for Research Abroad.

\section{References}

Ashi, J., Lallemant, S., Masago, H., and the Expedition 315 Scientists, 2009. Expedition 315 summary. In Kinoshita, M., Tobin, H., Ashi, J., Kimura, G., Lallemant, S., Screaton, E.J., Curewitz, D., Masago, H., Moe, K.T., and the Expedition 314/315/316 Scientists, Proc. IODP, 314/315/ 316: Washington, DC (Integrated Ocean Drilling Program Management International, Inc.). doi:10.2204/ iodp.proc.314315316.121.2009

Bangs, N.L.B., and Westbrook, G.K., 1991. Seismic modeling of the decollement zone at the base of the Barbados Ridge accretionary complex. J. Geophys. Res., [Solid Earth], 96(B3):3853-3866. doi:10.1029/90JB02138

Bilek, S.L., and Lay, T., 1999. Rigidity variations with depth along interplate megathrust faults in subduction zones. Nature (London, U. K.), 400:443-446. doi:10.1038/ 22739

Bray, C.J., and Karig, D.E., 1985. Porosity of sediments in accretionary prisms and some implications for dewatering processes. J. Geophys. Res., [Solid Earth], 90(B1):768778. doi:10.1029/JB090iB01p00768

Brown, K.M., and Ransom, B., 1996. Porosity corrections for smectite-rich sediments: impact on studies of compaction, fluid generation, and tectonic history. Geology, 24(9):843-846. doi:10.1130/

0091-7613(1996)024<0843:PCFSRS >2.3.CO;2

Erickson, S.N., and Jarrard, R.D., 1998. Velocity-porosity relationships for water-saturated siliciclastic sediments. J. Geophys. Res., [Solid Earth], 103(B12):30385-30406. doi:10.1029/98JB02128

Expedition 315 Scientists, 2009. Expedition 315 Site C0002. In Kinoshita, M., Tobin, H., Ashi, J., Kimura, G., Lallemant, S., Screaton, E.J., Curewitz, D., Masago, H., Moe, K.T., and the Expedition 314/315/316 Scientists, Proc. IODP, 314/315/316: Washington, DC (Integrated Ocean Drilling Program Management International, Inc.). doi:10.2204/iodp.proc.314315316.124.2009

Expedition 316 Scientists, 2009. Expedition 316 Site C0004. In Kinoshita, M., Tobin, H., Ashi, J., Kimura, G., Lallemant, S., Screaton, E.J., Curewitz, D., Masago, H., Moe, K.T., and the Expedition 314/315/316 Scientists, Proc. IODP, 314/315/316: Washington, DC (Integrated Ocean Drilling Program Management International, Inc.). doi:10.2204/iodp.proc.314315316.133.2009

Gettemy, G.L., and Tobin, H.J., 2003. Tectonic signatures in centimeter-scale velocity-porosity relationships of Costa Rica convergent margin sediments. J. Geophys.
Res., [Solid Earth], 108(B11):2494-2504. doi:10.1029/ 2001JB000738

Guo, J., Underwood, M., Hillix, D., Wu, H., Banno, H., and Shriniwar, U., 2009. Clay mineral assemblages from Nankai Trough and Kumano Basin, IODP Expeditions 315 and 316, NanTroSEIZE Stage 1. Eos, Trans. Am. Geophys. Union, 90(52)(Suppl.):T21C-1840. (Abstract) http:/ /www.agu.org/meetings/fm09/waisfm09.html

Hashimoto, Y., Tobin, H.J., and Knuth, M., 2010. Velocityporosity relationships for slope apron and accreted sediments in the Nankai Trough Seismogenic Zone Experiment, Integrated Ocean Drilling Program Expedition 315 Site C0001. Geochem., Geophys., Geosyst., 11:Q0AD05-Q0AD14. doi:10.1029/2010GC003217

Moore, J.C., and Saffer, D., 2001. Updip limit of the seismogenic zone beneath the accretionary prism of southwest Japan: an effect of diagenetic to low-grade metamorphic processes and increasing effective stress. Geology, 29(2):183-186. doi:10.1130/00917613(2001)029<0183:ULOTSZ>2.0.CO;2

Moore, J.C., and Vrolijk, P., 1992. Fluids in accretionary prisms. Rev. Geophys., 30(2):113-135. doi:10.1029/ 92RG00201

Raimbourg, H., Hamano, Y., Saito, S., Kinoshita, M., and Kopf, A., 2011. Acoustic and mechanical properties of Nankai accretionary prism core samples. Geochem., Geophys., Geosyst., 12:Q0AD10-Q0AD37. doi:10.1029/ 2010GC003169

Saffer, D.M., 2007. Pore pressure within underthrust sediment in subduction zones. In Dixon T.H., and Moore, J.C. (Eds.), The Seismogenic Zone of Subduction Thrust Faults: New York (Columbia University Press), 171-209.

Screaton, E.J., Kimura, G., Curewitz, D., and the Expedition 316 Scientists, 2009. Expedition 316 summary. In Kinoshita, M., Tobin, H., Ashi, J., Kimura, G., Lallemant, S., Screaton, E.J., Curewitz, D., Masago, H., Moe, K.T., and the Expedition 314/315/316 Scientists, Proc. IODP, 314/315/316: Washington, DC (Integrated Ocean Drilling Program Management International, Inc.). doi:10.2204/iodp.proc.314315316.131.2009

Tobin, H.J., and Moore, J.C., 1997. Variations in ultrasonic velocity and density with pore pressure in the décollement zone, northern Barbados Ridge accretionary prism. In Shipley, T.H., Ogawa, Y., Blum, P., and Bahr, J.M. (Eds.), Proc. ODP, Sci. Results, 156: College Station, TX (Ocean Drilling Program), 125-135. doi:10.2973/ odp.proc.sr.156.018.1997

Tobin, H.J., Moore, J.C., and Moore, G.F., 1994. Fluid pressure in the frontal thrust of the Oregon accretionary prism: experimental constraints. Geology, 22(11):979982. doi:10.1130/ 0091-7613(1994)022<0979:FPITFT>2.3.CO;2

Tsuji, T., Kimura, G., Okamoto, S., Kono, F., Mochinaga, H., Saeki, T., and Tokuyama, H., 2006. Modern and ancient seismogenic out-of-sequence thrusts in the Nankai accretionary prism: comparison of laboratoryderived physical properties and seismic reflection data. Geophys. Res. Lett., 33:L18309-L18312. doi:10.1029/ 2006GL027025 
von Huene, R., and Scholl, D.W., 1991. Observations at convergent margins concerning sediment subduction, subduction erosion, and the growth of the continental crust. Rev. Geophys., 29(3):279-316. doi:10.1029/91RG00969
Initial receipt: 28 December 2010

Acceptance: 18 May 2011

Publication: 15 August 2011

MS 314315316-217 
Figure F1. Location maps and stratigraphic summaries for NanTroSEIZE Sites C0001, C0002, and C0004. A. Map of Japan and bathymetry off Kii Peninsula. B. Location of drilling sites in a seismic profile of the Nankai accretionary prism off Kii Peninsula. C. Stratigraphic summary of Site C0004. D. Stratigraphic summary of Site C0002. Interpretations for stratigraphic summaries are from the "Expedition 316 Site C0004" chapter (Expedition 316 Scientists, 2009) and the "Expedition 315 Site C0002" chapter (Expedition 315 Scientists, 2009).
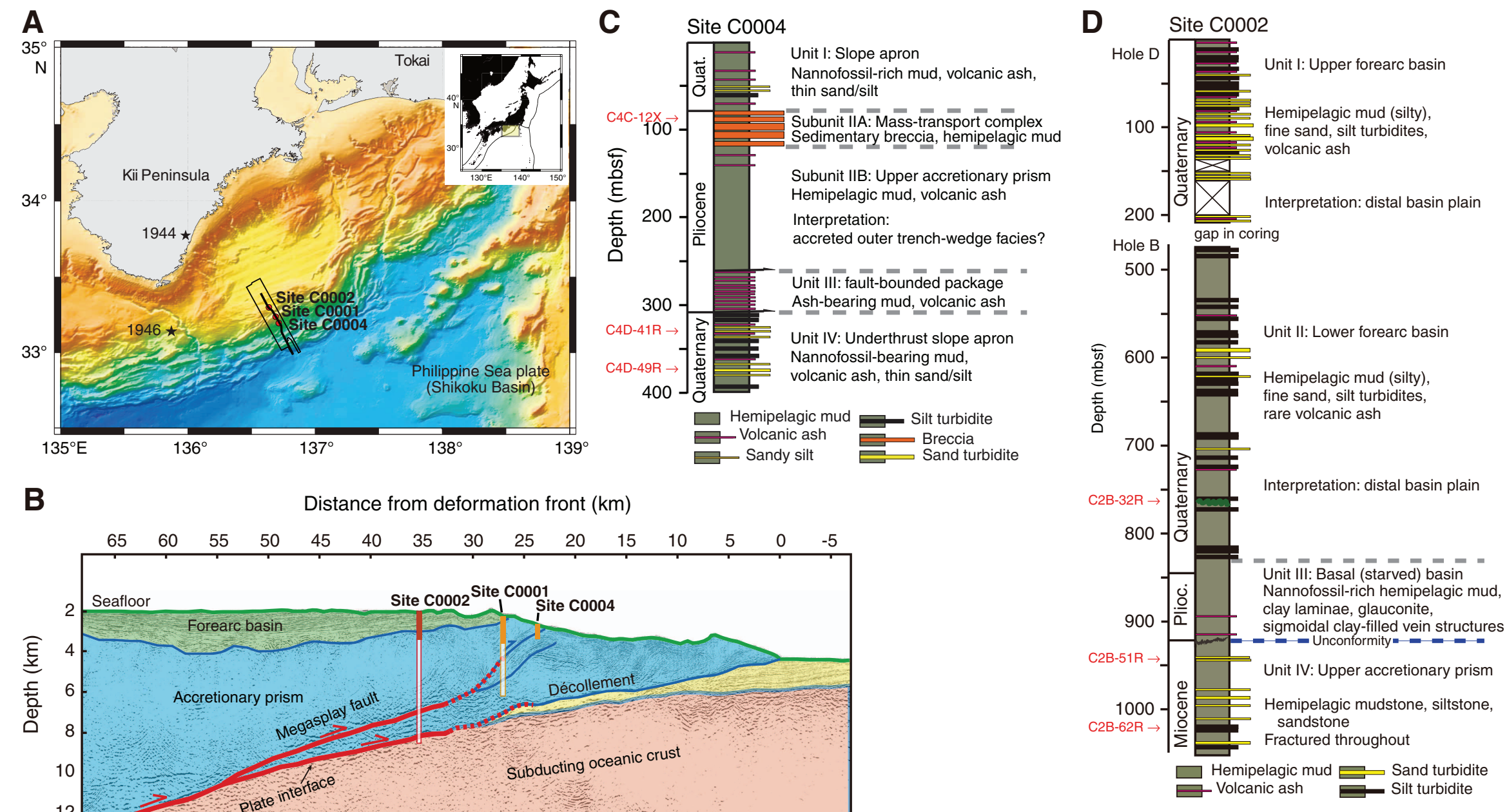

B Distance from deformation front $(\mathrm{km})$

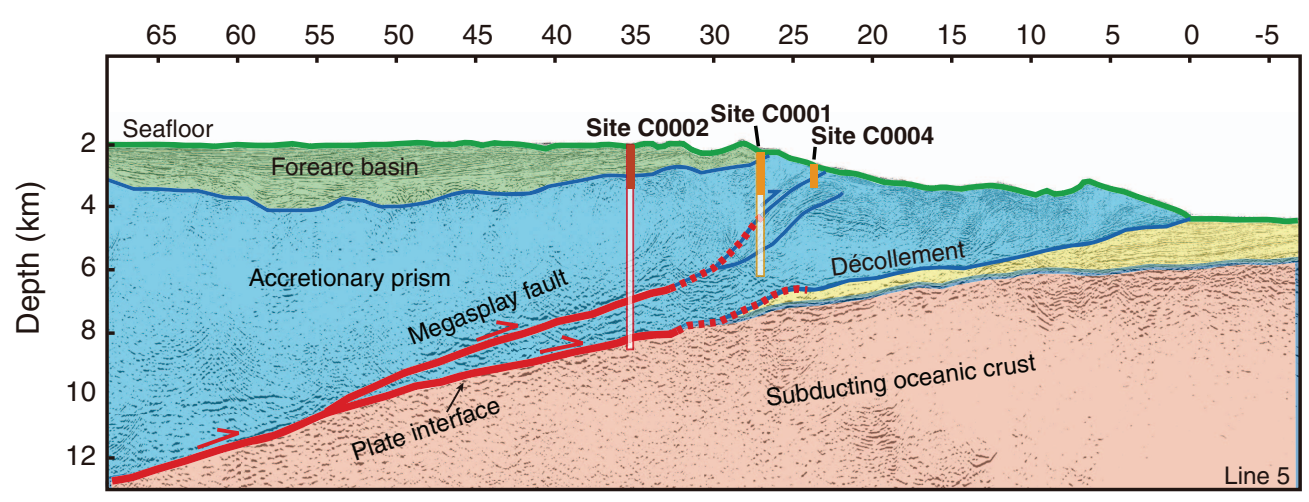


Figure F2. Effective pressure vs. compressional wave velocity.

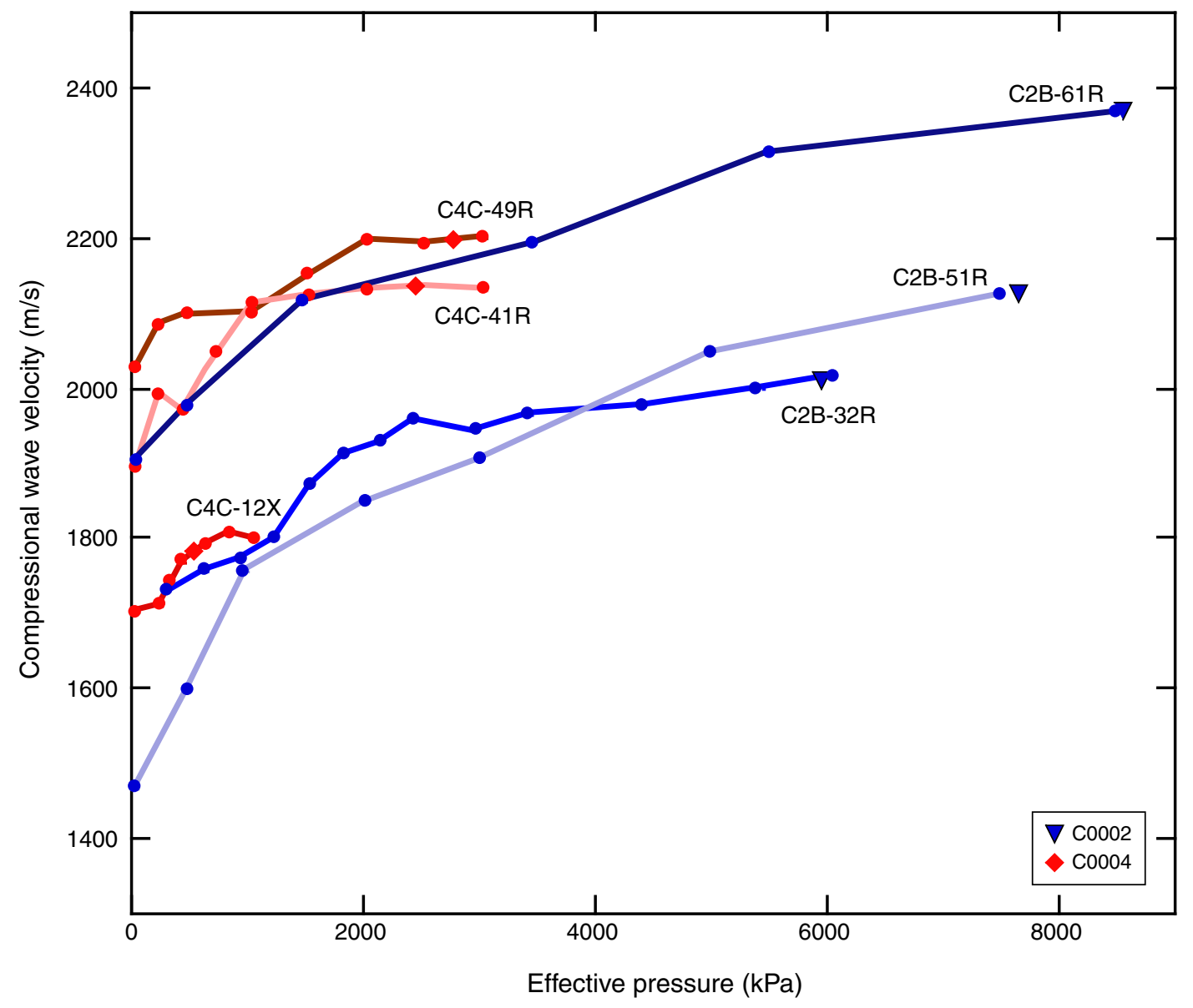


Figure F3. A. Compressional wave velocity vs. porosity, Sites C0001, C0002, and C0004. Global relationship between compressional wave velocity and porosity from Erickson and Jarrard (1998) is shown by solid gray lines ("normal compaction" for lower line and "high compaction" for upper line). Dashed lines indicate fitting lines for accreted sediments at Sites C0001 and C0002, underthrust sediments at Site C0004, and cover sediments (slope-apron sediments at Sites C0001 and C0004 and forearc basin sediments at Site C0002). B. Shear wave velocity vs. porosity, Sites $\mathrm{C0002}$ and C0004. C. Compressional wave velocity vs. shear wave velocity, Sites C0002 and C0004. D. Bulk and shear moduli vs. porosity, Sites C0002 and C0004. Sed. = sediment.
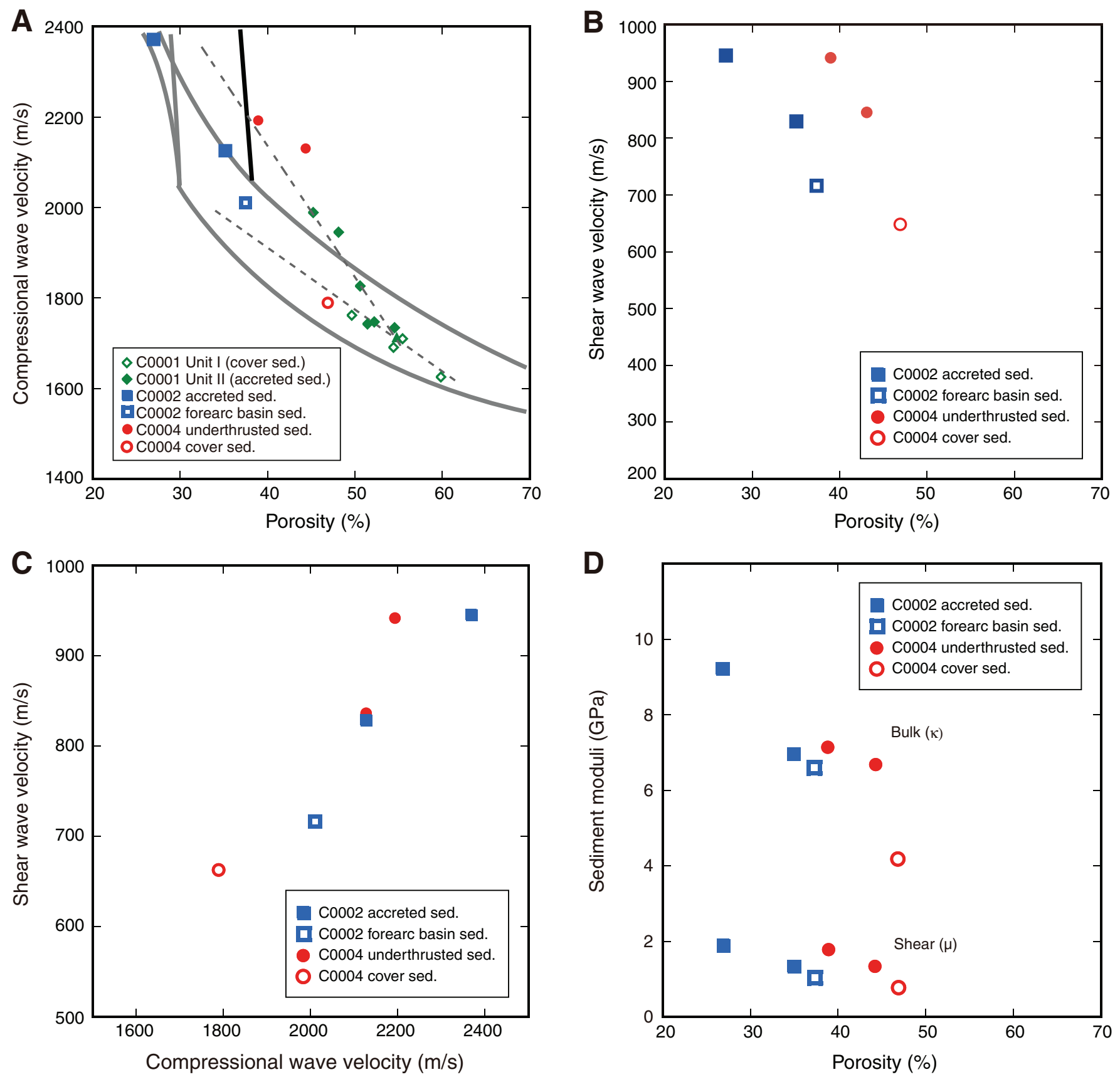
Table T1. Tested samples, depth, porosity, $V_{\mathrm{P}}, V_{\mathrm{S}}, V_{\mathrm{p}} / V_{\mathrm{S}}$, shear modulus, and bulk modulus, Sites C0002 and C0004.

\begin{tabular}{cccccccccc}
\hline & $\begin{array}{c}\text { Depth } \\
\text { Sample }\end{array}$ & $\begin{array}{c}\text { In situ effective } \\
\text { pressure (kPa) }\end{array}$ & $\begin{array}{c}\text { Uncorrected } \\
\text { porosity (\%) }\end{array}$ & $\begin{array}{c}\text { Corrected } \\
\text { porosity }(\%)\end{array}$ & $V_{\mathrm{P}}(\mathrm{m} / \mathrm{s})$ & $V_{\mathrm{S}}(\mathrm{m} / \mathrm{s})$ & $\begin{array}{c}\text { Shear } \\
V_{\mathrm{P}} / V_{\mathrm{S}}\end{array}$ & $\begin{array}{c}\text { Bulk } \\
\text { modulus } \\
(\mathrm{GPa})\end{array}$ & $\begin{array}{c}\text { modulus } \\
(\mathrm{GPa})\end{array}$ \\
\hline C2B-32R & 762.677 & 5947.3 & 47.70 & 37.35 & 2009.59 & 717.03 & 2.80 & 1.01 & 6.60 \\
C2B-51R & 938.82 & 7652.7 & 43.09 & 35.05 & 2125.86 & 829.30 & 2.56 & 1.33 & 6.98 \\
C2B-61R & 1023.57 & 8549.8 & 32.99 & 27.00 & 2367.91 & 946.87 & 2.50 & 1.88 & 9.24 \\
C4C-12X & 97.165 & 632.0 & 52.13 & 46.86 & 1788.17 & 663.02 & 2.70 & 0.79 & 4.18 \\
C4D-41R & 330.42 & 2453.4 & 40.93 & 44.32 & 2129.62 & 836.61 & 2.55 & 1.30 & 6.70 \\
C4D-49R & 367.62 & 2765.4 & 45.88 & 38.89 & 2193.30 & 943.23 & 2.33 & 1.76 & 7.17 \\
\hline
\end{tabular}

